\title{
Front Matter: Volume 8753
}

, "Front Matter: Volume 8753," Proc. SPIE 8753, Wireless Sensing, Localization, and Processing VIII, 875301 (7 June 2013); doi:

10.1117/12.2032005

SPIE Event: SPIE Defense, Security, and Sensing, 2013, Baltimore, Maryland, SPIE. United States 


\section{PROCEEDINGS OF SPIE}

\section{Wireless Sensing, Localization, and Processing VIII}

Sohail A. Dianat

Michael David Zoltowski

Editors

1-2 May 2013

Baltimore, Maryland, United States

Sponsored and Published by

SPIE 
The papers included in this volume were part of the technical conference cited on the cover and title page. Papers were selected and subject to review by the editors and conference program committee. Some conference presentations may not be available for publication. The papers published in these proceedings reflect the work and thoughts of the authors and are published herein as submitted. The publisher is not responsible for the validity of the information or for any outcomes resulting from reliance thereon.

Please use the following format to cite material from this book:

Author(s), "Title of Paper," in Wireless Sensing, Localization, and Processing VIII, edited by Sohail A. Dianat, Michael David Zoltowski, Proceedings of SPIE Vol. 8753 (SPIE, Bellingham, WA, 2013) Article CID Number.

ISSN: 0277-786X

ISBN: 9780819495440

Published by

SPIE

P.O. Box 10, Bellingham, Washington 98227-0010 USA

Telephone +1 3606763290 (Pacific Time) · Fax +1 3606471445

SPIE.org

Copyright (C) 2013, Society of Photo-Optical Instrumentation Engineers.

Copying of material in this book for internal or personal use, or for the internal or personal use of specific clients, beyond the fair use provisions granted by the U.S. Copyright Law is authorized by SPIE subject to payment of copying fees. The Transactional Reporting Service base fee for this volume is $\$ 18.00$ per article (or portion thereof), which should be paid directly to the Copyright Clearance Center (CCC), 222 Rosewood Drive, Danvers, MA 01923. Payment may also be made electronically through CCC Online at copyright.com. Other copying for republication, resale, advertising or promotion, or any form of systematic or multiple reproduction of any material in this book is prohibited except with permission in writing from the publisher. The CCC fee code is 0277-786X/13/\$18.00.

Printed in the United States of America.

Publication of record for individual papers is online in the SPIE Digital Library.

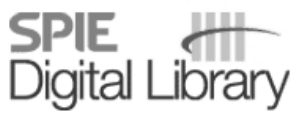

SPIEDigitallibrary.org

Paper Numbering: Proceedings of SPIE follow an e-First publication model, with papers published first online and then in print and on CD-ROM. Papers are published as they are submitted and meet publication criteria. A unique, consistent, permanent citation identifier (CID) number is assigned to each article at the time of the first publication. Utilization of CIDs allows articles to be fully citable as soon as they are published online, and connects the same identifier to all online, print, and electronic versions of the publication. SPIE uses a six-digit CID article numbering system in which:

- The first four digits correspond to the SPIE volume number.

- The last two digits indicate publication order within the volume using a Base 36 numbering

system employing both numerals and letters. These two-number sets start with 00, 01, 02, 03, 04, $05,06,07,08,09,0 A, 0 B \ldots 0 Z$, followed by 10-1Z, 20-2Z, etc.

The CID Number appears on each page of the manuscript. The complete citation is used on the first page, and an abbreviated version on subsequent pages. Numbers in the index correspond to the last two digits of the six-digit CID Number. 


\section{Contents}

$\checkmark$ Conference Committee

\section{SESSION 1 SENSOR NETWORKS}

875302 Multi-platform RF emitter localization using extremum seeking control [8753-1]

H. Al Issa, R. Ordóñez, Univ. of Dayton (United States)

875304 Optical communication line-of-sight analysis for dismounted warfighter [8753-3]

J. Geng, G. Nicholson, Naval Surface Warfare Ctr. (United States)

875305 Performance evaluation of $\mathrm{CCl}$ on the forward CDMA channel [8753-4]

M. S. Alam, S. Alsharif, A. H. M. Z. Hossain, Univ. of South Alabama (United States)

875306 Pulse based sensor networking using mechanical waves through metal substrates [8753-5] S. Lorenz, B. Dong, Q. Huo, W. J. Tomlinson Jr., S. Biswas, Michigan State Univ. (United States)

\section{SESSION 2 DIVERSITY AND MULTICARRIER TECHNIQUES}

875307 An investigation of crest factor and power amplifier back-off requirements for non-OFDM multicarrier modulations [8753-6]

J. Nieto, Harris Corp. (United States)

875308 Turbo MMSE equalizer for spread OFDM signal detection [8753-8]

A. Elghariani, M. Zoltowski, Purdue Univ. (United States)

875309 Noncoherent unitary space-time codes for wireless MIMO communications [8753-9]

X. Chen, E. Walker, Southern Univ. (United States)

\section{SESSION 3 MODULATION AND CHANNEL ESTIMATION}

8753 OB Quasi-coherent performance of convolutionally-coded continuous phase modulation [8753-11]

J. A. Norris, J. W. Nieto, Harris Corp. (United States)

8753 OD On robust soft-input soft-output demodulators for OFDM systems: when imperfect channel state information is present [8753-27]

C. Chen, M. D. Zoltowski, Purdue Univ. (United States)

$8753 \mathrm{OE}$ Power and spectrally efficient communications: a comparison of linear and nonlinear modulation schemes [8753-13]

C. Brown, P. J. Vigneron, Communications Research Ctr. Canada (Canada) 
8753 OF Estimating channel capacity and power transfer efficiency of a multi-layer acousticelectric channel [8753-14]

S. Chakraborty, K. R. Wilt, G. J. Saulnier, H. A. Scarton, Rensselaer Polytechnic Institute

(United States); P. K. Das, Univ. of California, San Diego (United States)

SESSION 4 DETECTION AND LOCALIZATION

8753 OG Low-complexity algorithms for spatio-temporal directional spectrum sensing with applications in cognitive radio [8753-15]

A. Madanayake, The Univ. of Akron (United States) and Univ. of Calgary (Canada);

C. Wijenayake, U. Potluri, J. Abeysekara, D. Mugler, The Univ. of Akron (United States)

$8753 \mathrm{OH} \quad$ Precise RFID localization in impaired environment through sparse signal recovery [8753-16]

S. Subedi, Y. D. Zhang, M. G. Amin, Villanova Univ. (United States)

8753 Ol Target position localization in a passive radar system through convex optimization [8753-17]

B. K. Chalise, Y. D. Zhang, M. G. Amin, Villanova Univ. (United States); B. Himed, Air Force Research Lab. (United States)

8753 0J Collaborative Beamfocusing Radio (COBRA) [8753-18]

J. P. Rode, M. J. Hsu, D. Smith, A. Husain, Ziva Corp. (United States)

8753 OK Estimation of the seismic disaster-stricken area based on wireless communication data [8753-19]

X. Zhang, X. Xie, B. Ning, G. Sun, National Earthquake Response Support Service (China)

\section{SESSION $5 \quad$ IMPLEMENTATION AND APPLICATIONS}

$8753 \mathrm{OL}$ Self-organized pulse switching for binary sensing and actuation [8753-20]

Q. Huo, B. Dong, S. Biswas, Michigan State Univ. (United States)

8753 OM Fast Fourier sampling for ultra-wide band digital receiver applications [8753-21]

C. Wu, S. Rajan, Defence Research and Development Canada, Ottawa (Canada)

8753 ON Combination of spatial diversity and parallel decision feedback equalizer in a Single Input Multiple Output underwater acoustic communication system operating at very high frequencies [8753-22]

V. Skoro Kaskarovska, P.-P. Beaujean, Florida Atlantic Univ. (United States)

875300 Regularization in radio tomographic imaging [8753-24]

R. Sundaram, Gannon Univ. (United States); R. Martin, Air Force Institute of Technology

(United States); C. Anderson, U.S. Naval Academy (United States)

Author Index

iv 


\title{
Conference Committee
}

\author{
Symposium Chair
}

Kenneth R. Israel, Major General (USAF Retired) (United States)

Symposium Cochair

David A. Whelan, Boeing Defense, Space, and Security

(United States)

Conference Chairs

Sohail A. Dianat, Rochester Institute of Technology (United States)

Michael David Zoltowski, Purdue University (United States)

Conference Program Committee

John W. Nieto, Harris Corporation (United States)

Raghuveer M. Rao, U.S. Army Research Laboratory (United States)

Yimin D. Zhang, Villanova University (United States)

Session Chairs

1 Sensor Networks

John W. Nieto, Harris Corporation (United States)

2 Diversity and Multicarrier Techniques

Michael David Zoltowski, Purdue University (United States)

3 Modulation and Channel Estimation

James A. Norris, Harris Corporation (United States)

4 Detection and Localization

John W. Nieto, Harris Corporation (United States)

5 Implementation and Applications

James A. Norris, Harris Corporation (United States) 